\title{
SIMULATION OF VENTILATION EFFICIENCY, TEMPERATURES, AND RELATIVE HUMIDITIES IN EMPLACEMENT DRIFTS AT YUCCA MOUNTAIN, NEVADA, USING MONTE CARLO AND COMPOSITE THERMAL-PULSE METHODS
}

\author{
John B. Case, P.E. \\ Bechtel/SAIC Company \\ Las Vegas, Nevada 89144
}

\author{
David Buesch \\ U.S. Geological Survey \\ Las Vegas, Nevada 89144
}

\begin{abstract}
Predictions of waste canister and repository driftwall temperatures as a function of space and time are of fundamental importance to evaluating pre-closure and postclosure design requirements and performance assessment of the proposed repository for spent nuclear fuel and high-level radioactive waste at Yucca Mountain, Nevada. Variations in the lithostratigraphic features in densely welded and crystallized rocks of the 12.8-million-year-old Topopah Spring Tuff, especially the porosity resulting from lithophysal cavities, are projected 50 to $800 \mathrm{~m}$ from the Enhanced Characterization of the Repository Block cross drift to a simulated "Panel 1" emplacement drift. Lithophysal cavity porosity varies from 0.00 to $0.05 \mathrm{~cm}^{3} / \mathrm{cm}^{3}$ in the middle nonlithophysal zone and from 0.03 to $0.28 \mathrm{~cm}^{3} / \mathrm{cm}^{3}$ in the lower lithophysal zone. Many thermal properties are related to lithophysal cavity porosity, and computer code titled "Monte Carlo Simulation of Ventilation" (MCSIMVENT) has been developed for simulating statistical variability and uncertainty along the simulated emplacement drift. The MCSIMVENT code, which is based on a composite thermalpulse calculation, is used to calculate pre-closure ventilation efficiency and peak post-closure temperatures and relative humidities along the simulated emplacement drift for as much as 1,000 years. Variations in lithophysal porosity along the drift can result in a range in peak waste-package temperatures from 160 to $180^{\circ} \mathrm{C}$ for a single emplacement drift.
\end{abstract}

\section{INTRODUCTION}

Predictions of waste canister and repository driftwall temperatures as a function of space and time are of fundamental importance to evaluating pre-closure and postclosure design requirements and performance assessment of the proposed repository for high-level radioactive waste at Yucca Mountain, Nevada. The proposed repository is located approximately $160 \mathrm{~km}$ northwest of Las Vegas and will be in the densely welded and crystallized part of the 12.8-millionyear-old Topopah Spring Tuff (age from [1]). Sensitivity studies indicate variations in rock features and properties such as porosity result in different rock-mass mechanical and thermal properties along the proposed emplacement drifts. A computer code titled "Monte Carlo Simulation of Ventilation" (MCSIMVENT) has been developed for simulating preclosure ventilation efficiency and peak post-closure temperatures and relative humidities on the basis of a single realization of in situ thermal conductivity during both the preclosure and post-closure periods. This paper presents a description of the (1) projection of porosity values from the Enhanced Characterization of the Repository Block (ECRB) cross drift tunnel to a simulated emplacement drift, (2) MCSIMVENT code, (3) composite thermal-pulse calculation upon which the code is based, and (4) Monte Carlo simulations and uncertainty of pre-closure ventilation efficiency and post-closure temperatures and relative humidities.

\section{GEOLOGIC CONDITIONS ALONG THE SIMULATED EMPLACEMENT DRIFTS}

The general lithostratigraphic framework of Yucca Mountain was first described in a series of maps and reports from the 1960's through the 1980's, initially using geologic map relations of rock units exposed at the ground surface and later with surface-based boreholes [2, 3]. From 1992 to 2003, the lithostratigraphic framework was refined and the distribution of units documented in surface-based boreholes, tunnels, and tunnel-based boreholes [4, 5, and 6]. Many of the lithostratigraphic units (especially the thicker formations and many of the thinner informal units) are correlated across the Yucca Mountain area and this type of layering of units is referred to as stratiform. In general, the lithostratigraphic units in the area of the proposed repository are tilted with strikes toward the north and dip toward the east [7].

The host rocks of the proposed repository host horizon formed as a pyroclastic flow deposit that developed several lithostratigraphic features as it became densely welded and crystallized. On the basis of the types of welding (nonwelded, or partially, moderately, or densely welded), materials (glass or crystalline), and the abundance of features such as lithophysae and spots, the Topopah Spring Tuff is divided into a hierarchical lithostratigraphic system of members, zones, and subzones (and locally intervals) [8; 9]. Lithophysae, which vary in size and abundance, formed during or shortly after welding of the deposit $[9 ; 10]$ and consist of four parts. From the center outward, a typical lithophysa has (1) a cavity where the vapor phase accumulated, (2) a coating of vaporphase-deposited minerals, (3) a rim of light gray, crystallized material, that typically has porosity ranging from 0.20 to 0.40 $\mathrm{cm}^{3} / \mathrm{cm}^{3}$, and (4) a thin border of light gray to reddish purple, crystallized material between the rim and matrix-groundmass 
[8; 11]. Spots do not have a central cavity or vapor-phase mineral coating (or the cavity and vapor-phase mineral coating are very small and thin), but are similar to rims in the types and forms of minerals and amounts of porosity. The crystallized material between the lithophysae and spots (and whatever lithic clasts there might be) is the matrixgroundmass.

In the current (2004) proposed repository host horizon, about 4.4 percent of the emplacement drifts are in the upper lithophysal zone, 12.4 percent are in the middle nonlithophysal zone, 80.3 percent are in the lower lithophysal zone, and 3.0 percent are in the lower nonlithophysal zone (Alan Linden, Bechtel/SAIC Company, written commun., 2003). In the proposed Panel 1 emplacement drifts, the first area to be developed, the rocks are in the middle nonlithophysal and lower nonlithophysal zones. The middle nonlithophysal zone typically has less than $0.01 \mathrm{~cm}^{3} / \mathrm{cm}^{3}$ lithophysal cavity porosity in the upper and lower nonlithophysal subzones, 0.03 to $0.05 \mathrm{~cm}^{3} / \mathrm{cm}^{3}$ in the transition subzone, and 0.03 to $0.05 \mathrm{~cm}^{3} / \mathrm{cm}^{3}$ in the lithophysae-bearing subzone [8; 9]. Informal subzones of the upper and lower lithophysal and lower nonlithophysal zone have not been defined; however, lateral and vertical variations in lithostratigraphic characteristics are consistent with subzones in these zones. Detailed mapping in the lower lithophysal zone exposed in the cross drift indicates numerous variations in lithostratigraphic features along the drift [4]. These variations include the abundance and sizes of lithophysae, rims, and spots and the calculated porosity of these features.

A calculation method was developed that replicates the basic stratiform characteristics within the rocks, but allows for variation in lithophysal porosity as observed in the ECRB cross drift. The calculated lithophysal cavity porosities along the cross drift [4] have been used to approximate the lithophysal cavity porosities along a simulated emplacement drift in Panel 1. This approximation of lithophysal cavity porosity consists of 7 steps:

1. In the area of the ECRB cross drift and Panel 1 emplacement drifts, the contact of the middle nonlithophysal and lower lithophysal zones has a strike of $345^{\circ}$ and a dip of $5.8^{\circ}$. The geometric relations of drifts and rocks are used to determine the apparent dips of rocks in the drifts and to project values from the cross drift (with and azimuth of $229^{\circ}$ ) to the simulated emplacement drift (with an azimuth of $252^{\circ}$ ).

The lithophysal cavity porosities in segments (or "windows") along the cross drift are projected along the apparent dip into 5 -m-tall vertical sections.

2. In the cross drift, lithophysal porosity values vary from 0.00 to $0.05 \mathrm{~cm}^{3} / \mathrm{cm}^{3}$ in the middle nonlithophysal zone and 0.03 to $0.28 \mathrm{~cm}^{3} / \mathrm{cm}^{3}$ in the lower lithophysal zone. These values do not include the "large lithophysae" that are defined as being at least $0.5 \mathrm{~m}$ in diameter and locally are as much as 8 percent of the rock.

3. A (vertical) composite stratigraphic section of lithophysal cavity porosity in the middle nonlithophysal and lower lithophysal zones from the cross drift is projected 50 to $800 \mathrm{~m}$ to the Panel 1 area for the simulated emplacement drift.

4. Based upon the projection, the intercept length of the simulated emplacement drift in the middle nonlithophysal zone is $250 \mathrm{~m}$, with the remaining length of $350 \mathrm{~m}$ in the lower lithophysal zone.

5. For simplicity, these intercept lengths are rounded to $200 \mathrm{~m}$ and $400 \mathrm{~m}$, respectively, to fit within the framework of six, 100-m long Continuously Stirred Tank Reactors (CSTRs, i.e., a well-mixed volume element) that are used to simulate the drift in MCSIMVENT.

6. Calculations in MCSIMVENT are currently based on a two-component porosity model with one component being the lithophysal cavity porosity and the second component being the porosity of the rock material; however, the rock material actually includes the matrix-groundmass, border, rim, and spot material. Porosity of the matrix-groundmass is about 0.104 $\mathrm{cm}^{3} / \mathrm{cm}^{3}$ [11]. The mean contribution to the rock porosity by rims and spots probably varies from 0.02 to $0.05 \mathrm{~cm}^{3} / \mathrm{cm}^{3}$ for the rocks in the simulated emplacement drift [4].

7. Variations in the lithostratigraphic features along the cross drift have been projected to a simulated Panel 1 emplacement drift and provides a geologic framework for the calculations used in the MCSIMVENT code. The simulated drift has about $250 \mathrm{~m}$ (rounded to $200 \mathrm{~m}$ ) of the middle nonlithophysal, which includes the upper and lower nonlithophysal subzones and the lithophysae-bearing subzone, and lithophysal cavity porosities vary from 0.00 to $0.05 \mathrm{~cm}^{3} / \mathrm{cm}^{3}$. The simulated drift also transects about $350 \mathrm{~m}$ (rounded to $400 \mathrm{~m}$ ) of the upper part of the lower lithophysal zone, and the lithophysal cavity porosities vary from 0.03 to $0.28 \mathrm{~cm}^{3} / \mathrm{cm}^{3}$.

\section{MONTE CARLO SIMULATION OF VENTILATION (MCSIMVENT)}

The MCSIMVENT program structure includes analyses of rock mass thermal conductivity based on laboratory measurements of matrix porosity and saturation, field measurements of lithophysal cavity porosity, and field and laboratory measurements of thermal conductivity (Figure 2). Further, the MCSIMVENT code uses repository design parameters such as the ventilation flow rate $\left(15 \mathrm{~m}^{2} / \mathrm{sec}\right)$, the drift diameter $(5.5 \mathrm{~m})$, and emplacement drift spacing $(81 \mathrm{~m})$ in estimating pre-closure ventilation efficiency and postclosure repository temperatures and relative humidities.

The MCSIMVENT code addresses several forms of uncertainty, including primary uncertainties in the rock porosities and solids (mineralogical components), and the code evaluates model uncertainty in alternate thermal conductivity models that can be specified. Relations of the matrix thermal conductivity to the mineral-solids thermal conductivity, and matrix porosity can be evaluated based on models $[12,13$, and 14]. Several other models can be used to assess the relation of the rock-mass thermal conductivity to the rock-matrix thermal conductivity, and to the air-filled lithophysal porosity [15; and 16]. Further, as subsequently described, the MCSIMVENT code accounts for spatial variability as suggested by variations in stratigraphic features along the emplacement drift. 
Ventilation and temperature calculations are developed for a series of multiple CSTRs. The ventilation-calculation technique is based on the use of a steady-state approximation, and the principle of superposition as presented below.

Use of the steady-state approximation, sometimes referred to as a quasi-steady-state approximation, allows the energy balance equations to be written with no time derivatives, only as algebraic equations that can be solved. The ventilated drift can be represented as segments, where each CSTR has uniform driftwall, canister, and air temperatures throughout the segment. The progress of the calculation through time is exactly like that of integrating a function using Euler's method for numerical integration [17].

Processing of multiple realizations using the Monte Carlo method was greatly facilitated by development of a composite thermal-pulse method for estimating the response of the driftwall temperature to a unit pulse of energy. The composite thermal-pulse ventilation calculation uses an analytical approach based on a combination of the solutions for an internally bounded cylinder in an infinite region and for a semi-infinite slab.

Temperature response can be calculated based upon superposition of temperature responses for a linear system from individual constant fluxes applied over short time intervals in such a manner that the constant fluxes approximate the arbitrary flux.

The dimensionless temperature $(\theta)$ in an infinite region bounded internally by a cylinder is given by [18]:

$$
\theta \equiv \frac{K \cdot v}{Q \cdot a}=-\frac{2}{\pi} \int_{0}^{\infty}\left(1-e^{-\xi^{2} \cdot \tau}\right) \cdot \frac{J_{0}(\xi) \cdot Y_{1}(\xi)-Y_{0}(\xi) \cdot J_{1}(\xi)}{\left.\xi^{2} \cdot\left[J_{1}^{2}(\xi)+Y_{1}^{2}(\xi)\right]\right]} \cdot d \xi
$$

\section{Equation 1}

where

$\mathrm{J}_{0}(\xi) \quad$ zero order Bessel function of the first kind,

$J_{1}(\xi)$ first order Bessel function of the first kind,

$\mathrm{Y}_{0}(\xi)$ zero order Bessel function of the second kind,

$\mathrm{Y}_{1}(\xi) \quad$ first order Bessel function of the second kind

$\mathrm{K}$ Thermal Conductivity $(\mathrm{W} /(\mathrm{m} \cdot \mathrm{K})$,

$\xi \quad$ Temporary variable used in integration

$\checkmark$ Temperature (K)

$\kappa \quad$ Thermal Diffusivity $\left(\mathrm{m}^{2} / \mathrm{sec}\right)$

Q Unit Heat Loading Applied at drift wall surface $(\mathrm{W} / \mathrm{m})$,

a Drift radius (m), and

$\mathrm{t}$ Time (sec).

One-dimensional models can be developed based upon finite difference calculations for a nonhomogeneous media or a semi-infinite slab for a homogeneous media. The temperature at the surface of a semi-infinite slab is [18]:

$$
v=\frac{2 \cdot F_{0}}{K} \cdot \sqrt{\frac{\kappa \cdot t}{\pi}}
$$

Equation 2

where

$\mathrm{F}_{0} \quad$ Surface heat loading corresponding to a unit line load of $\pi^{*} \mathrm{a} / \mathrm{L}$

L Drift spacing between the simulated emplacement drift adjacent emplacement drifts (m).

Comparisons of temperature responses between ANSYS finite element calculations (a standard engineering code used for this application; Veraun Chipman, Bechtel/SAIC Company, written commun., 2003), a semi-infinite homogeneous slab model, and the composite thermal-pulse temperature response from the MCSIMVENT calculations using drift spacing of 81 $\mathrm{m}$ and $160 \mathrm{~m}$ showed good agreement between the two approaches (Figure 3). The MCSIMVENT calculation combines Equations 1 and 2 resulting in a composite temperature response that is the maximax of the internally bounded cylinder and semi-infinite slab responses. However, the composite method generates a single realization in seconds compared to approximately 30 person-hours to run the ventilation simulation using ANSYS. The composite thermalpulse methods presented above substantially reduced the computer processing time to allow Monte Carlo simulation of variations in the repository drift thermal properties.

The MCSIMVENT relative humidity calculations are performed using three empirical relations: (1) the volumetric moisture content versus the driftwall rock temperature (Darren Jolley, Bechtel/SAIC Company, written commun., 2004), (2) the moisture retention relation for the host rock (John Case Bechtel/SAIC Company, written commun., 2003), and (3) the Kelvin Equation that relates the relative humidity to the matrix potential [19] for temperatures below the boiling point of water. For temperatures above the boiling point of water, the relative humidities are calculated under the assumption that water boils at atmospheric pressure at the repository host horizon, and that the relative humidities can be calculated from the ratio of the atmospheric pressure to the saturation vapor pressure that is a function of the waste-package surface temperature. Comparisons between the relative humidity calculation from MCSIMVENT and the Multiscale Thermohydrologic model used by the YMP (Thomas Buscheck, Lawrence Livermore National Laboratory, written commun., 2004) shows good agreement in the context that the Multiscale model uses slightly different properties such as smaller mean lithophysal cavity porosities and includes the entire repository and edge-cooling effects.

\section{MCSIMVENT SIMULATION}

Using the statistical and spatial variation data and projection techniques described in steps 1 to 6 of the Geologic Conditions section, a series of 190 simulations of spatial variations in lithophysal cavity porosity along a simulated emplacement drift have been calculated (only five of which are depicted in Figure 4). These simulations show smaller 
lithophysal cavity porosity in the middle nonlithophysal zone and larger porosity with greater variability in the lower lithophysal zone. Porosity variations are used to assess the thermal conductivity and thermal diffusivity along the drift; for example, the variations in thermal properties for a single realization are shown in Figure 5. The smaller lithophysal cavity porosity of the middle nonlithophysal zone results in a larger thermal conductivity (and thermal diffusivity) values than the larger lithophysal porosity of the lower lithophysal zone.

Using MCSIMVENT with the composite thermal-pulse method presented above, accounting for canister heat generation, and including repository drift spacing of $81 \mathrm{~m}$, a ventilation air flow rate of $15 \mathrm{~m}^{3} / \mathrm{sec}$ for pre-closure and 0 $\mathrm{m}^{3} / \mathrm{sec}$ for post-closure, and multiple thermal properties realizations, ventilation efficiencies and temperature predictions during the pre- and post-closure periods were calculated. The pre-closure results of these analyses indicate that 75 to 90 percent of the heat is removed by the ventilation airstream and ventilation efficiencies and temperatures are predicted to occur within a narrow range. Pre-closure results also indicate (1) a prediction of sequential increases in driftwall temperatures for each segment of the simulated drift as air flows from CSTR1 to CSTR6 (Figure 6), and (2) the ventilation efficiency of the CTRS's decreases from CSTR1 to CSTR6 (Figure 7). During the pre-closure period, the results indicate driftwall temperature and ventilation efficiency along the drift is relatively insensitive to variations in rock thermal properties (Figures 6 and 7). The relations of temperature and ventilation efficiency are a result of ambient temperature air entering the first CSTR and being heated rapidly due to a large temperature difference between the air and rock. Along the drift the higher air temperatures from previous CSTRs result in the air being heated at a lower rate (i. e. lower efficiency). During the post-closure period, peak driftwall and canister temperatures depend on the thermal conductivity of the host horizon (Figure 6). The uncertainty in post-closure temperature and relative humidity responses (Figure 8 ) is dominated by uncertainty in thermal conductivity, which is related to the variations in porosity from the abundances of lithostratigraphic features (primarily, but not exclusively, lithophysal cavities) along the simulated drifts. In comparisons with the wider range and typically lower temperatures and higher relative humidities in the Multiscale model, the larger lithophysal cavity porosities and smaller variances in porosity used along the simulated drift in the MCSIMVENT calculations results in narrower and typically higher temperatures and lower relative humidities (Figure 8).

\section{CONCLUSIONS}

Spatial distribution of lithostratigraphic features and their thermal properties are important constraints in the design and performance of the proposed high-level nuclear waste repository. The composite thermal-pulse method was developed to allow a rapid evaluation of variations in thermal properties along a simulated emplacement drift. Geological studies in the ECRB cross drift characterized porosity variations from lithostratigraphic features such as lithophysal cavities in the strataform units of the proposed repository host rocks. A calculation method was developed that honors the basic strataform characteristics of the rocks and accounts for spatial variability within the lithostratigraphic units, resulting in multiple realizations of rock and lithophysal porosity along the simulated emplacement drift. These realizations were evaluated with the composite thermal-pulse method to simulate pre-closure and post-closure performance. Results of the study indicate that variations in rock properties for the proposed pre-closure ventilation rate do not result in large variations in ventilation efficiency because the ventilation air stream removes 75 to 90 percent of the heat during the 50-year pre-closure period. However, results of the analysis show post-closure driftwall, canister, and relative humidity environments depend strongly on thermal conductivity that, in turn, are dependant on the lithostratigraphic characteristics of the host rocks. This MCSIMVENT modeling indicates that with appropriate details of lithostratigraphic features from mapping emplacement drifts, variations in temperature and relative humidity along each drift can be simulated to evaluate and potentially optimize conditions at the drift scale.

\section{ACKNOWLEDGMENTS}

This work was completed with cooperation of the U.S. Geological Survey and Bechtel/SAIC (the management and operations contractor on the Yucca Mountain Project) for the U.S. Department of Energy, Office of Civilian Radioactive Waste Management. The MCSIMVENT code is currently undergoing documentation, and will be made available from the U. S. Department of Energy.

\section{REFERENCES}

[1] Sawyer, D.A., Fleck, R.J., Lanphere, M.A., Warren, R.G., Broxton, D.E., and Hudson, M.R., 1994, Episodic caldera volcanism in the Miocene southwestern Nevada volcanic field: Revised stratigraphic framework, ${ }^{40} \mathrm{Ar} /{ }^{39} \mathrm{Ar}$ geochronology, and implications for magmatism and extension: Geological Society of America Bulletin, v. 106, p. 1304-1318.

[2] Scott, R.B., and Bonk, J., 1984, Preliminary Geologic Map of Yucca Mountain, Nye County, Nevada, with Geologic Sections: U. S. Geological Survey Open-File Report 84-494.

[3] Spengler, R.W., and K.F. Fox, Jr., 1989. Stratigraphic and Structural Framework of Yucca Mountain, Nevada: Radioactive Waste Management and the Nuclear Fuel Cycle, vol. 13, p. 21-36.

[4] Buesch, D.C., and Eatman, G.L.W., 2003, Lithostratigraphic features and porosity in the lower lithophysal zone of the Topopah Spring Tuff in the cross drift at Yucca Mountain, Nevada: Geological Society of America Abstracts with Programs, v. 35, no. 6, p. A435.

[5] Buesch, D.C., and Spengler, R.W., 1999, Stratigraphic framework of the North Ramp Area of the Exploratory Studies Facility, Yucca Mountain, Nevada: in Rousseau, J.P., Kwicklis, E.M., and Gilles, D.C., (eds), Hydrogeology of the Unsaturated Zone, North Ramp Area of the Exploratory Studies Facility, Yucca Mountain, 


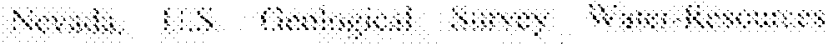

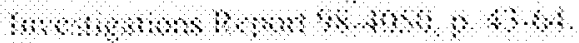

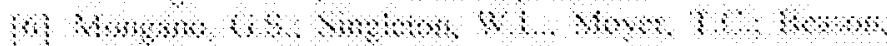

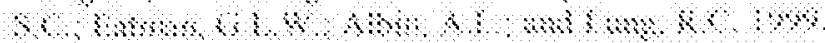

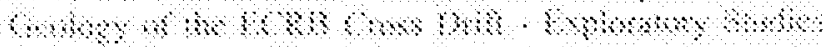

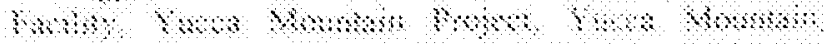

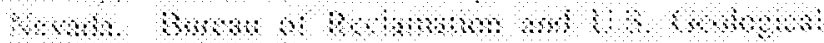

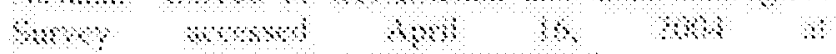

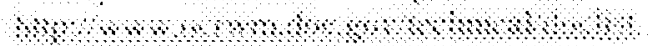

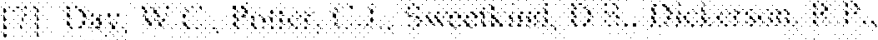

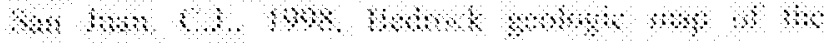

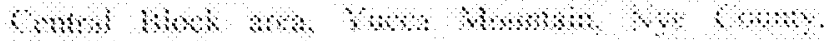

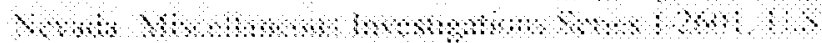

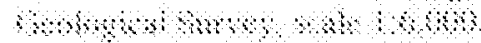

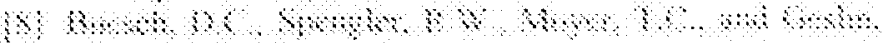

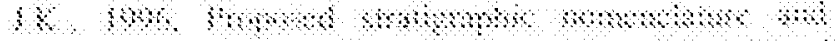

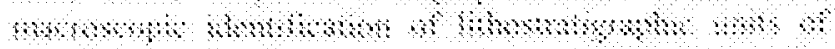

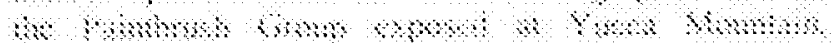

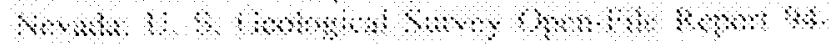
\$ 14

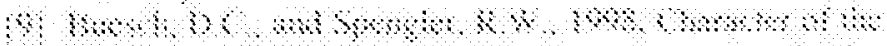

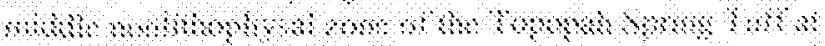

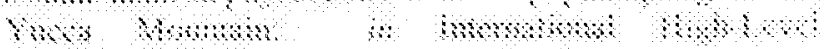

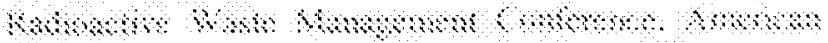

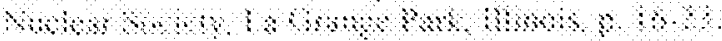

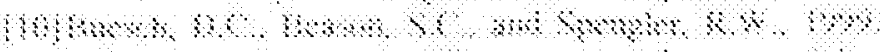
समwक mmo

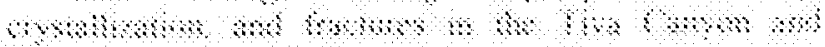

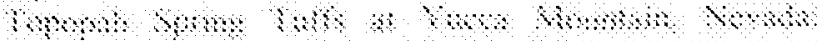

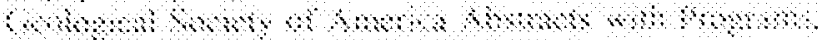

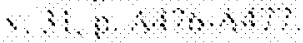

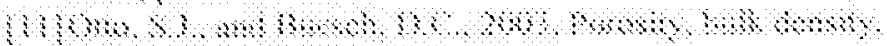

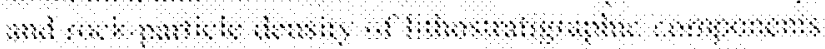

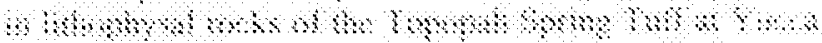

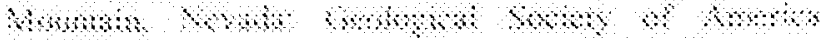

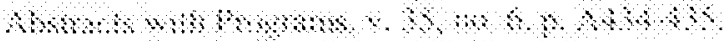

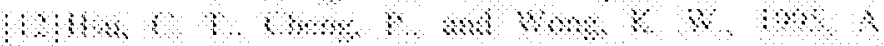

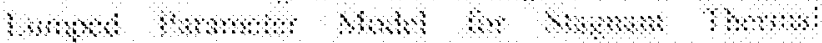

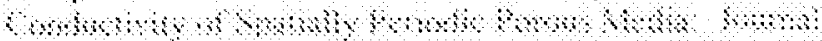

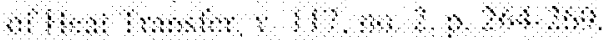

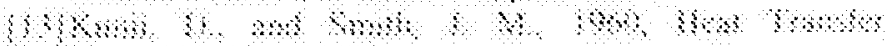

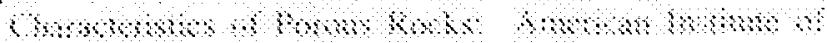

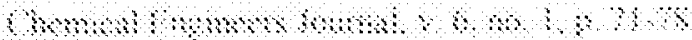

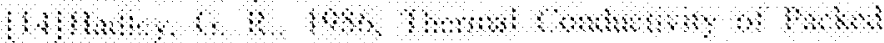

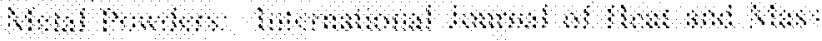

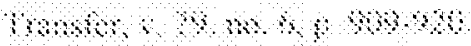

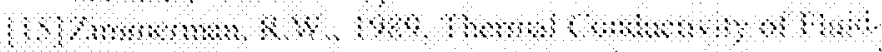

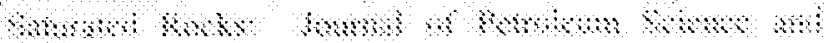

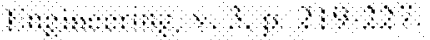

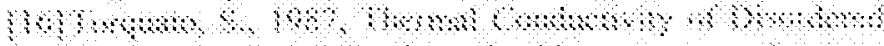

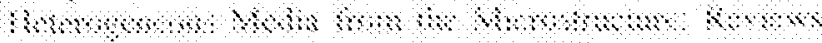

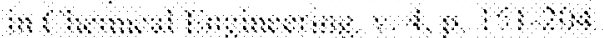

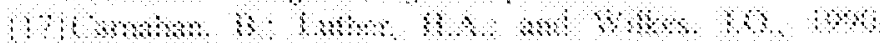

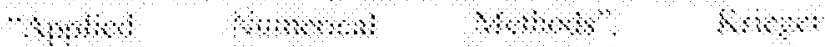

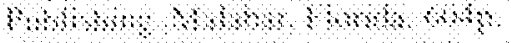

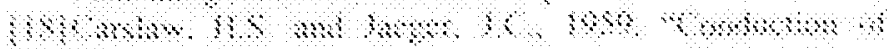

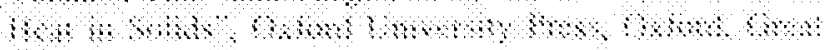

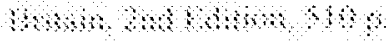

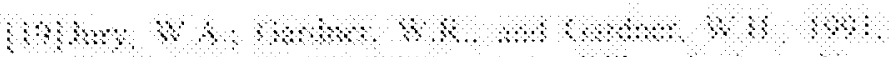

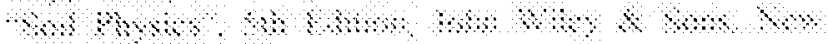
\$. \$\& \$ 13.

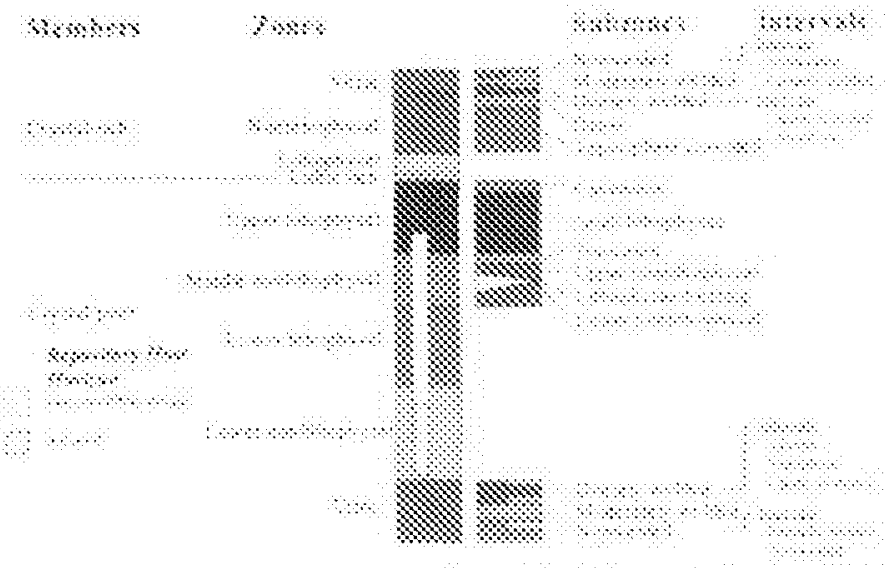

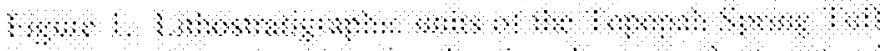

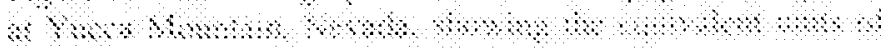

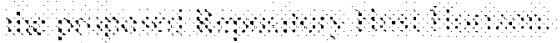

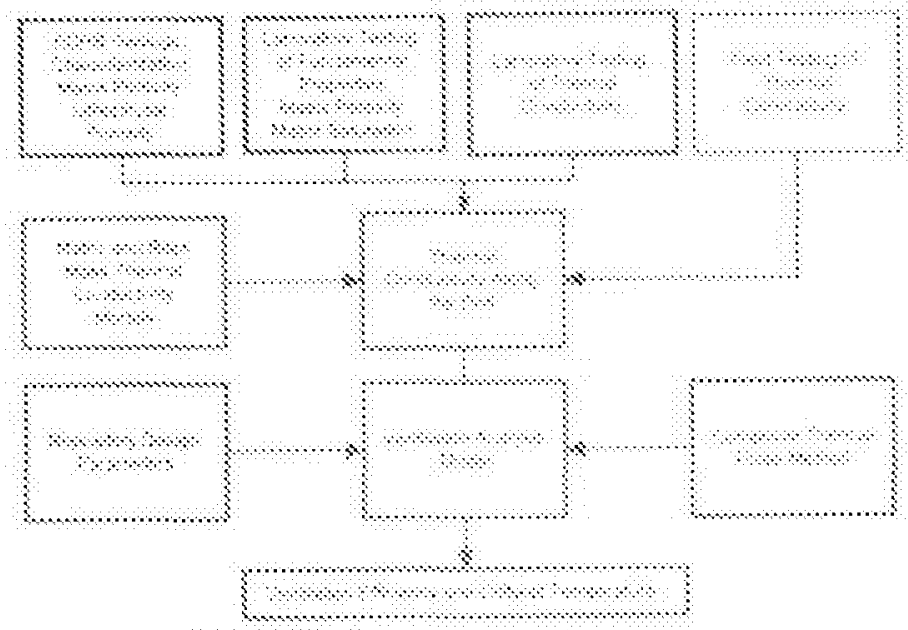

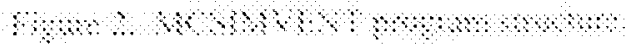

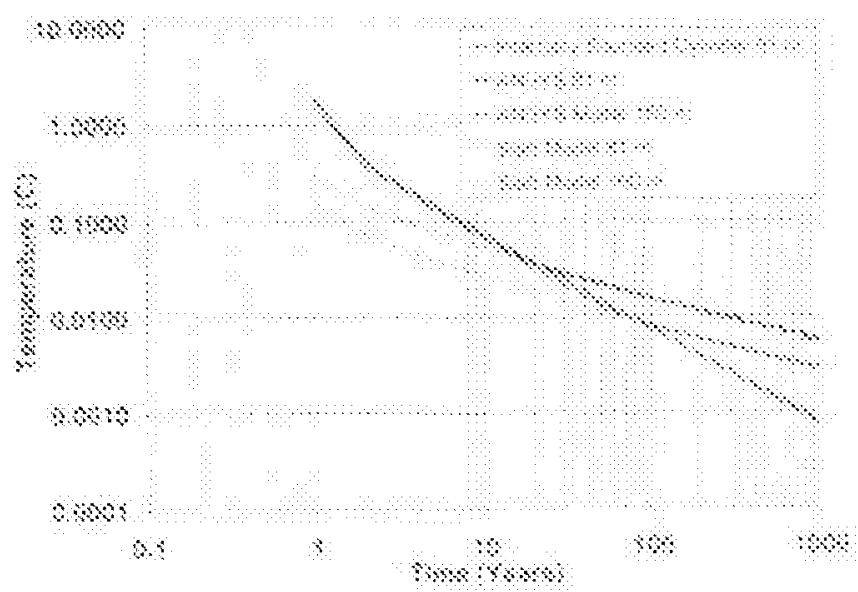

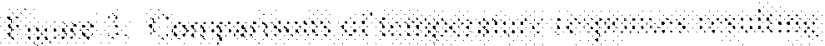

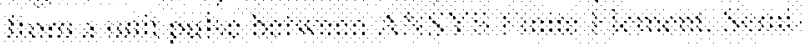

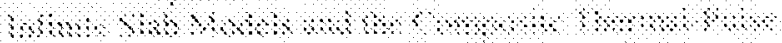

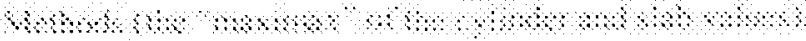




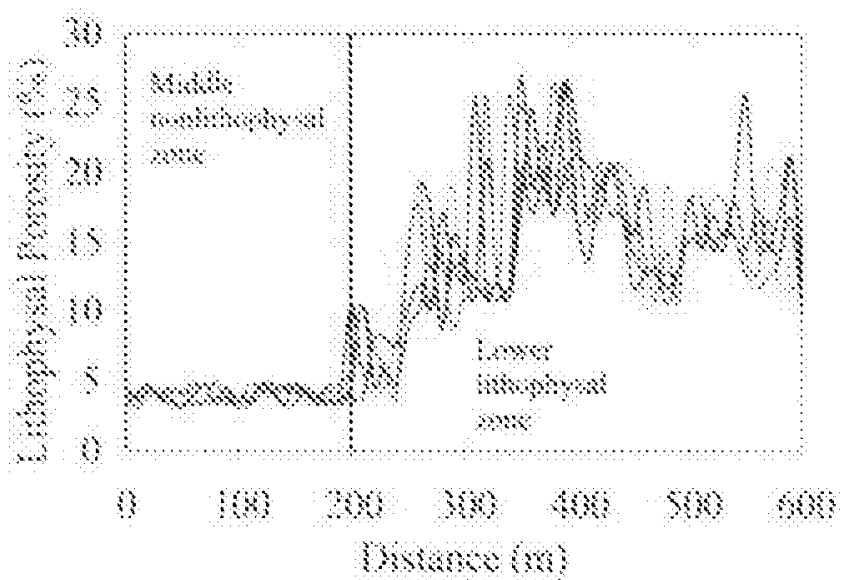

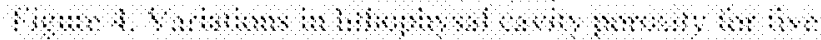

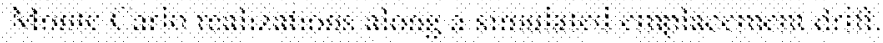

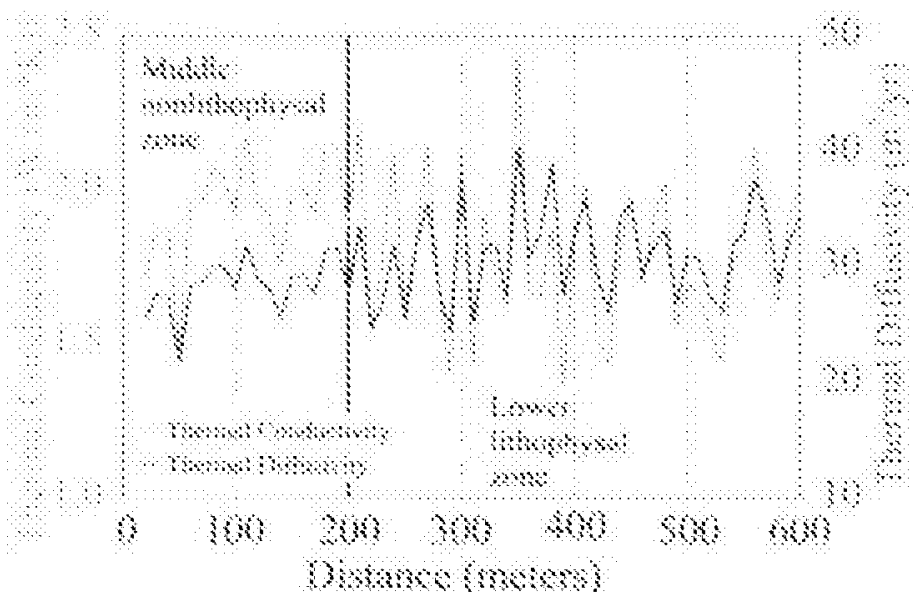

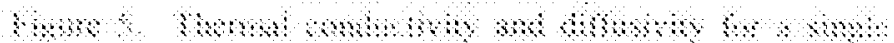

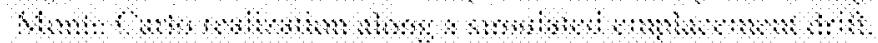

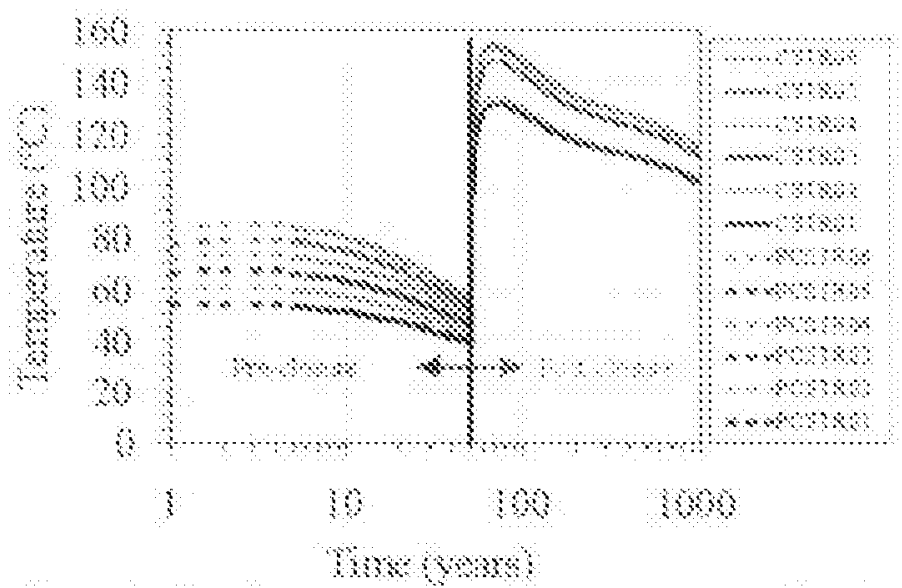

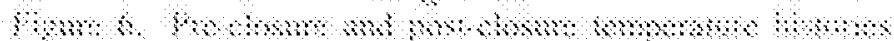

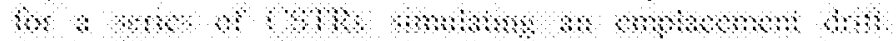

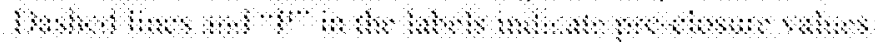

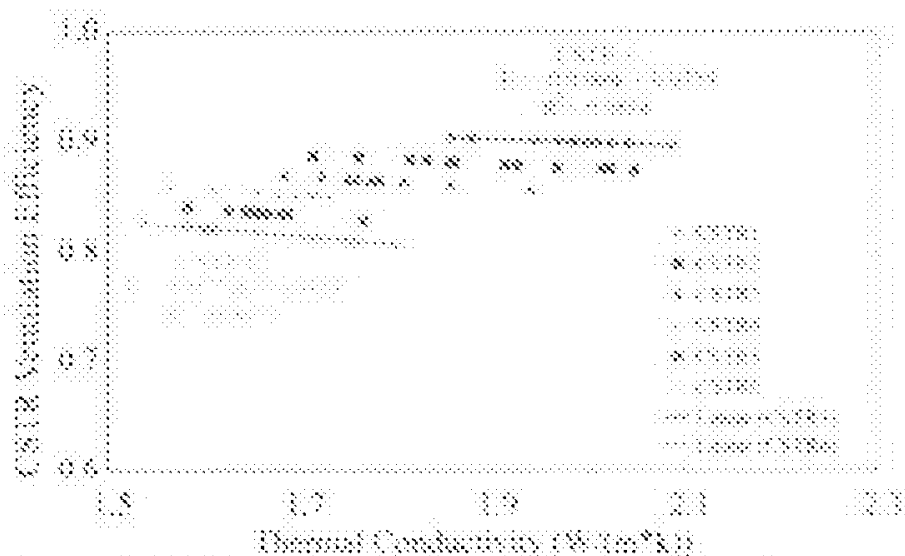

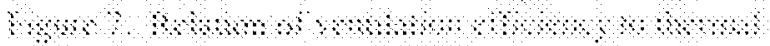

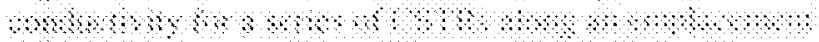

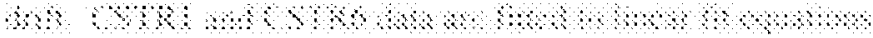

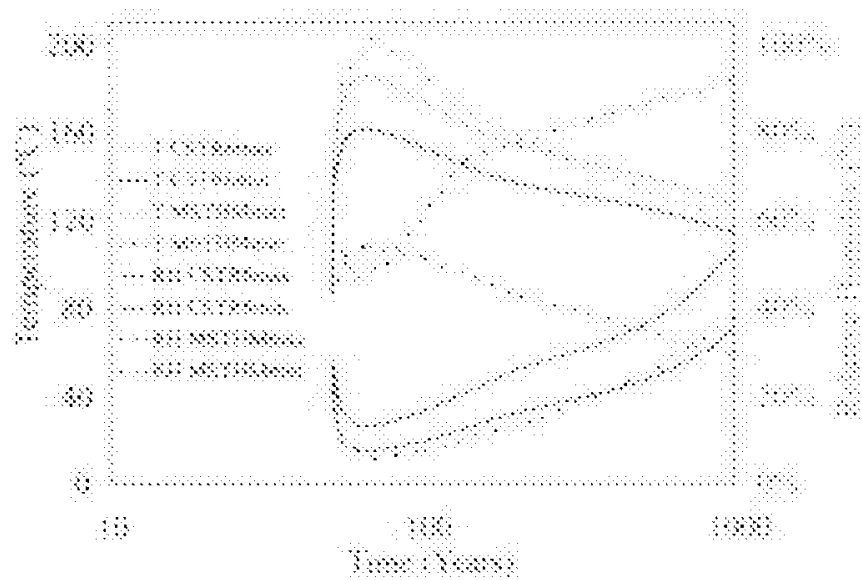

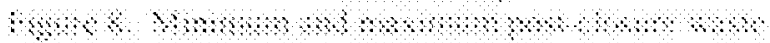

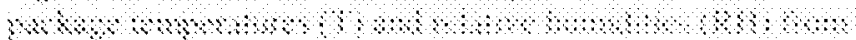

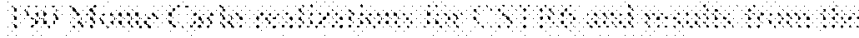

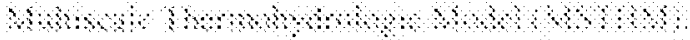

